\title{
Jurist-Diction
}

Volume 3 No. 5, September 2020

\section{Pertanggungjawaban Pidana Terhadap Orang Tua yang Menjadikan Anak Kandung sebagai Pengemis dan Pengamen}

\author{
Fanny Julianti
}

Fannyjulianty70@gmail.com

Universitas Airlangga

\author{
How to cite: \\ Fanny Julianti, \\ 'Pertanggungjawaban Pidana \\ Terhadap Orang Tua yang \\ Menjadikan Anak Kandung \\ sebagai Pengemis dan \\ Pengamen' (2020) Vol. 3 No. 5 \\ Jurist-Diction. \\ Histori artikel: \\ Submit 17 Juli 2020; \\ Diterima 14 Agustus 2020; \\ Diterbitkan 1 September 2020. \\ DOI: \\ 10.20473/jd.v3i5.21975
}

\begin{abstract}
Abstrak
Anak adalah generasi penerus bangsa yang harus dilindungi oleh berbagai pihak yang dimulai dari lingkungan terkecil yaitu keluarga, masyarakat, pemerintah maupun negara. Kejahatan yang dilakukan kepada anak sebagai korban sering terjadi tetapi masyarakat tidak merespon kejahatan tersebut sehingga pada akhirnya kejahatan tersebut dianggap wajar terlebih dilakukan oleh Orang Tua dari anak tersebut. Tindak pidana yang sering dilakukan oleh Orang Tua terhadap anak kandung yaitu dengan sengaja menelantarkan kebutuhan primer maupun sekunder dari anak tersebut. Pada dasarnya penelantaran terhadap anak termasuk dalam kekerasan secara sosial yang menimbulkan luka secara psikis maupun fisik dan tentunya sangat membekas di dalam ingatan anak yang menjadi korban penelantaran tersebut. Penelantaran terhadap anak tersebut adalah awalan untuk melakukan eksploitasi secara ekonomi dengan modus operandi menjadikan anak kandung sebagai pengemis dan pengamen demi memenuhi kebutuhan hidup keluarga yang seharusnya bukan sebagai tanggung jawab seorang anak dalam keluarga.Pelaku yang menjadikan anak sebagai pengemis dan pengamen adalah sekup terkecil dalam masyarakat yaitu Orang Tua. Pertanggungjawaban pidana bagi orang yang dengan sengaja mengeksploitasi anak secara ekonomi dengan modus operandi menjadikan anak tersebut sebagai pengemis dan pengamen diatur dalam Undang-Undang Nomor 35 Tahun 2014 Tentang Perubahan atas Undang-Undang Nomor 23 Tahun 2002 tentang Perlindungan Anak.

Kata Kunci: Orang Tua; Eksploitasi Ekonomi; Pertanggungjawaban Pidana.
\end{abstract}

\section{Pendahuluan}

Anak adalah dambaan dari setiap keluarga yang akan menjadi penerus keluarga sehingga anak ialah aset bangsa yang mempunyai peran sebagai generasi penerus bangsa, peran strategis tersebut menekankan posisi anak sebagai makhluk yang harus mendapat perlindungan atas hak-hak yang telah dimilikinya. Indonesia masuk dalam 192 negara yang ikut meratifikasi konvensi hak-hak anak (Convention on The Rights of The Child) pada tahun 1990 secara tidak langsung maka Indonesia 
berkewajiban untuk memenuhi hak-hak anak bagi semua anak, salah satunya hak anak untuk memperoleh proses hukum yang adil (due process of law) dan bermartabat. Negara berkewajiban untuk memasukkan hasil konvensi ke dalam lingkungan nasional yaitu dengan melaksanakan ratifikasi terlebih dahulu atas hasil konvensi sebelum dituangkan dalam undang-undang. ${ }^{1}$

Keluarga mempunyai fungsi dan peran utama yang sangat penting dalam tumbuh kembang anak karena keluarga ialah unit yang paling kecil dalam masyarakat yang memiliki peran, cakupan substansi dan ruang lingkup yang sangat luas sehingga untuk mempermudah dalam memberikan alternatif pemberdayaan keluarga untuk melindungi anak dalam keluarga. ${ }^{2}$

Keluarga adalah unit terkecil tetapi memiliki fungsi yang sangat besar karena kebutuhan primer maupun kebutuhan sekunder dari si anak seharusnya dapat terpenuhi dengan baik termasuk hak nya untuk mendapatkan perlindungan, dan perawatan penuh dari keluarga tersebut.

Sumber Daya Manusia yang berkualitas dapat terwujud denganmempersiapkan sejak dini jaminan perlindungan dan kesejahteraan yang memadai agar terpenuhinya kebutuhan untuk kelangsungan hidup, tumbuh kembang, perlindungan bagi anak dan juga peran serta dalam masyarakat. Kenyataan untuk menciptakan Sumber Daya Manusia yang berkualitas terbentur oleh 2 (dua) faktor yaitu kondisi anak dan juga situasi lingkungan. Permasalahan yang sering dialami terhadap anak ialah perlakuan salah, eksploitasi dan penelantaran terhadap anak yang kurang mendapat perhatian baik dalam keluarga maupun masyarat dan tak jarang bila perlakuan tersebut mengakibatkan luka psikis maupun luka fisik terhadap anak tersebut. ${ }^{3}$

Anak yang menjadi pengemis dan pengamen didasarkan pada beberapa faktor yaitu faktor kemiskinan atau perekonomian dalam suatu keluarga yang sulit, faktor dalam keluarga yang mengakibatkan anak mencari pelampiasan lain sehingga anak

\footnotetext{
${ }^{1}$ Romli Atmasasmita, Pengantar Hukum Pidana Internasional (Rafika Aditama 2000). [52].

${ }^{2}$ Sholeh Soeaidy, Zulkhair, Dasar Hukum Perlindungan Anak (Novindo Pustaka Mandiri 2001).[2].

${ }^{3}$ ibid.[12].
} 
tersebut menjadi pengemis dan pengamen akibat orang tua tidak memperhatikan atau sengaja menelantarkan anak tersebut, faktor geografis karena daerah tersebut terpencil atau terisolasi, terbatas dalam prasarana, faktor ekologi, faktor teknologi, dan pertumbuhan penduduk yang tinggi tetapi tidak diimbangi dengan lapangan pekerjaan yang ada, faktor umur, dan juga faktor pendidikan.

Praktik pengemis maupun pengamen yang melibatkan anak termasuk dalam eksploitasi secara ekonomi yang menjadikan orang tua sebagai pelaku utama dalam tindakan eksploitasi tersebut. Anak yang dengan sengaja dijadikan alat untuk mengemis maupun mengamen di jalan demi mendapatkan keuntungan yang pada akhirnya anak tersebut turut membantu perekonomian keluarga yang seharusnya usia mereka dihabiskan untuk belajar dan bermain bersama teman-teman sebayanya bukan untuk membantu menyambung kehidupan keluarga. Tindakan yang menjadikan anak sebagai alat untuk mendapatkan keuntungan pribadi tidak dapat dibenarkan karena termasuk dalam tindak pidana meskipun pelaku dari kejahatan tersebut adalah orang tua kandung.

\section{Rumusan Masalah}

1. Apakah perbuatan orang tua yang menjadikan anak kandung sebagai pengemis dan pengamen merupakan tindak pidana?

2. Bagaimanakah pertanggungjawaban pidana orang tua yang menjadikan anak, kandung sebagai pengemis dan pengamen?

\section{Perbuatan Orang Tua yang Menjadikan Anaknya sebagai Pengemis dan Pengamen merupakan Tindak Pidana}

Kepentingan nasional meliputi banyak kepentingan dilihat dari berbagai tingkat yang dipusatkan pada kepastian keamanan (meliputi: lingkungan, politik, energi, pangan, militer dan ekonomi), kebebasan, kesejahteraan dan keadilan. Dilihat dari kepentingan dalam berbagai tingkat maka, kepentingan nasional dapat berupa sebagai berikut: sosial; politik; ekonomi; lingkungan; pendidikan; moral; kebijakan dalam negeri dan luar negeri (kebijakan dalam negeri bertujuan untuk 
memberikan penjelasan terhadap pembangunan nasional yang diprioritaskan dalam hal memberikan kepastian); Penelitian dan pengembangan.

Tindak pidana ialah terjemahan dari "strafbaar feit" yaitu tindak pidana adalah perbuatan yang dilarang dan diancam dengan pidana, terhadap barang siapa yang melanggar larangan tersebut. perbuatan tersebut itulah yang harus dirasakan oleh masyarakat sebagai suatu hambatan tata pergaulan yang dicita-citakan oleh masyarakat. Menurut Moeljatno, unsur-unsur tindak pidana dibagi sebagai berikut: ${ }^{4}$

a. Perbuatan itu harus merupakan perbuatan manusia;

b. Perbuatan itu harus dilarang dan diancam dengan hukuman oleh undang-undang;

c. Perbuatan itu bertentangan dengan hukum (melawan hukum);

d. Harus dilakukan oleh seseorang yang dapat dipertanggungjawabkan;

e. Perbuatan itu harus dapat dipersalahkan kepada si pembuat.

Sementara itu, Loebby Loqman menyatakan bahwa unsur-unsur tindak pidana meliputi: ${ }^{5}$

a. Perbuatan manusia baik aktif maupun pasif;

b. Perbuatan itu dilarang dan diancam dengan pidana oleh undang-undang;

c. Perbuatan itu dianggap melawan hukum;

d. Perbuatan tersebut dapat dipersalahkan;

e. Pelakunya dapat dipertanggungjawabkan.

Sedangkan menurut EY. Kanter dan SR. Sianturi, unsur-unsur tindak pidana ialah: ${ }^{6}$

a. Subjek;

b. Kesalahan;

c. Bersifat melawan hukum (dan tindakan);

d. Suatu tindakan yang dilarang atau diharuskan oleh undang- undang/perundangan dan terhadap pelanggarnya diancam dengan pidana;

e. Waktu, tempat, dan keadaan (unsur objektif lainnya).

Dalam penjelasan tersebut, Kanter dan Sianturi menegaskan bahwa tindak pidana adalah suatu tindakan pada tempat, waktu, dan keadaan tertentu, yang dilarang (atau diharuskan) dan diancam dengan pidana oleh undang-undang, bersifat melawan hukum, serta dengan kesalahan dilakukan oleh seseorang (yang mampu bertanggung jawab).

4 Erdianto Effendi, S.H.,M.Hum, Hukum Pidana Indonesia (Suatu Pengantar), (PT. Refika Aditama, Cetakan Kesatu 2011).[98].

5 ibid.[99].

6 ibid. 
Dalam kasus orang tua yang menjadikan anak kandung sebagai pengamen dan pengemis termasuk dalam suatu tindak pidana karena orang tua melakukan kesengajaan dengan membiarkan anak kandung mengamen dan mengemis di jalanan. Bila dilihat maka, tindakan orang tua tersebut telah memenuhi unsurunsur suatu tindak pidana dan jelas perbuatan yang dengan sengaja membiarkan anak kandung mereka yang seharusnya menikmati masa anak-anak, mendapat pendidikan dan kehidupan layak tidak terpenuhi pada akhirnya mereka ikut membantu perekonomian keluarga dengan menjadi pengemis dan pengamen.

Eksploitasi terhadap anak yang dilakukan oleh orang tua dengan sengaja menjadikan anak sebagai pengemis dan pengamen tergolong dalam kejahatan kekerasan terhadap anak yang mengakibatkan kerugian atau bahaya secara fisik, psikologis, atau finansial baik yang dialami individu maupun kelompok. Kejahatan tersebut termasuk dalam perbuatan yang disengaja dan menimbulkan kerugian atau bahaya terhadap anak-anak secara fisik maupun emosional dengan berbagai bentuk tingkah laku, yang disertai dengan ancaman fisik secara langsung oleh orang tua atau orang dewasa lainnya sehingga mengakibatkan penelantaran kebutuhan anak.

Anak yang sengaja dijadikan pengemis dan pengamen oleh orang tua akan berdampak yang sangat buruk bagi anak yaitu anak akan merasa terbebani karena memberikan perlukaan fisik, mental, atau seksual yang umumnya dilakukan orangorang yang mempunyai tanggung jawab terhadap kesejahteraan anak.

Deklarasi dalam Sidang Umum Perserikatan Bangsa-Bangsa (PBB) memuat asas tentang hak-hak anak, yaitu: ${ }^{7}$ Anak berhak menikmati semua hak-haknya sesuai ketentuan yang terkandung dalam deklarasi ini.

1. Anak berhak memperoleh perlindungan khusus dan harus memperoleh kesempatan yang dijamin oleh hukum dan sarana lain agar menjadikannya mampu untuk mengembangkan diri secara fisik, kejiwaan, moral, spiritual, dan kemasyarakatan dalam situasi yang sehat, normal sesuai dengan kebebasan dan harkatnya.

2. Anak sejak dilahirkan berhak akan nama dan kebangsaan.

3. Anak berhak dan harus dijamin secara kemasyarakatan untuk tumbuh kembang

7 ibid. [45]. 
secara sehat.

4. Anak yang cacat fisik, mental, dan lemah kedudukan sosialnya akibat keadaan tertentu harus memperoleh pendidikan, perawatan, dan perlakuan khusus.

5. Anak harus dibesarkan di bawah asuhan dan tanggung jawab orang tuanya sendiri, dan bagaimanapun harus diusahakan agar tetap berada dalam suasana yang penuh kasih sayang, sehat jasmani, dan rohani.

6. Anak berhak mendapat pendidikan wajib secara gratis sekurang-kurangnya di tingkat sekolah dasar.

7. Dalam keadaan apapun anak harus didahulukan dalam menerima perlindunagn dan pertolongan.

8. Anak harus dilindungi dari segala bentuk kealpaan, kekerasan, penghisapan. Ia tidak boleh dijadikan subjek perdagangan. Anak tidak boleh bekerja sebelum usia tertentu, ia tidak boleh dilibatkan dalam pekerjaan yang dapat merugikan kesehatan atau pendidikannya, maupun yang dapat mempengaruhi perkembangan tubuh, jiwa, dan akhlaknya.

9. Anak harus dilindungi dari perbuatan yang mengarah ke dalam bentuk diskriminasi sosial, agama maupun bentuk-bentuk diskriminasi lainnya.

Moeljatno merumuskan hukum pidana yang meliputi hukum pidana materiil dan hukum pidana formil, seperti yang dimaksud oleh Enschede-Heijder dengan hukum pidana sistematik, sebagai berikut: "hukum pidana adalah sebagian daripada keseluruhan hukum yang berlaku di suatu negara, yang mengadakan dasar-dasar dan aturan-aturan untuk:

1) Menentukan perbuatan-perbuatan mana yang tidak boleh dilakukan, yang dilarang, dengan disertai ancaman atau sanksi yang berupa pidana tertentu bagi barangsiapa melanggar larangan tersebut.

2) Menentukan kapan dan dalam hal-hal apa kepada mereka yang telah melanggar larangan-larangan itu dapat dikenakan atau dijatuhi sebagaimana yang diancamkan.

3) Menentukan dengan cara bagaimana pengenaan pidana itu dapat dilaksanakan apabila ada orang yang disangka telah melanggar larangan tersebut.

Sehingga Moeljatno merumuskan hukum pidana materiil pada butir 1 dan butir 2, sedangkan hukum pidana formil pada butir 3. Ia merumuskan hukum pidana materiil dengan memisahkan perumusan delik dan sanksinya pada butir 1 sedangkan pertanggungjawaban pidana pada butir $2 .^{8}$

${ }^{8}$ Andi Hamzah,Asas-Asas Hukum Pidana Edisi Revisi, Cetakan Kedua (Rineka Cipta).[5]. 
Tindak pidana mempunyai 3 unsur, yaitu: 1) perbuatan yang dilarang, 2) akibat dari perbuatan itu yang menjadi dasar alasan mengapa perbuatan itu dilarang, 3) sifat melanggar hukum dalam rangkaian sebab akibat itu yang melingkupi perbuatan, akibat, dan juga sifat melanggar hukum. sebagian besar tindak pidana mempunyai unsur kesengajaan atau opzet bahwa dengan kesengajaan yang bersifat tujuan (oogmerk) si pelaku dapat dipertanggungjawabkan yang dimana pelaku benar-benar menghendaki untuk melakukan perbuatan tersebut untuk mencapai tujuan sehingga akibat tersebt bisa menjadi pokok alasan diadakan ancaman hukuman pidana. ${ }^{9}$

\section{Tanggung Jawab Orang Tua yang Menjadikan Anak Kandung sebagai Pengemis dan Pengamen}

Hukum pidana ialah bagian dari keseluruhan hukum yang berlaku dalam suatu negara, yang mempunyai dasar-dasar dan aturan-aturan untuk: a. menentukan perbuatanperbuatan yang tidak boleh dilakukan, yang dilarang, dengan disertai ancaman atau sanksi berupa pidana tertentu bagi barang siapa melanggar tersebut; b. menentukan kapan dan dalam hal-hal apa kepada mereka yang telah melanggar larangan-larangan itu sehingga dapat dikenakan atau dijatuhi pidana sebagaimana yang telah diancamkan, c. menentukan dengan cara bagaimana pengenaan pidana itu dapat dilaksanakan apabila ada orang yang disangka telah melanggar larangan tersebut. ${ }^{10}$

Ada 2 (dua) faktor untuk menentukan apakah seseorang mempunyai kemampuan untuk bertanggung jawab, dengan melihat dari faktor akal dan faktor kehendak. Faktor kehendak bukan merupakan faktor dalam menentukan mampu tidaknya orang bertanggung jawab yaitu soal kesengajaan dan kealpaan. Soal "tidak dipidana jika tidak ada kesalahan".

Tindak pidana merupakan perbuatan yang dilarang dan diancam dengan pidana barang siapa yang melakukannya "suatu perbuatan yang melanggar aturan hukum dapat dipidana, apabila sudah dinyatakan bersalah. Pertanggungjawaban atas

\footnotetext{
9 Wirjono Prodjodikoro, Asas-Asas Hukum Pidana di Indonesia (Refika Aditama 2008).[66].

${ }^{10}$ Didik Endro P., Hukum Pidana (Khusus Untuk Mahasiswa Fakultas Hukum Universitas Airlangga 2010).
} 
perbuatan yang dilakukan seseorang yang bertujuan untuk menentukan kesalahan dari tindak pidana yang ia lakukan tersebut. ${ }^{11}$

Barda Nawawi Arief menjelaskan pertanggungjawaban pidana bisa dilakukan apabila telah diketahui siapa yang dapat dipertanggungjawabkan. Siapa yang dapat dipertanggungjawabkan juga mempunyai arti bahwa harus dipastikan terlebih dahulu siapa yang dapat dinyatakan sebagai suatu pembuat tindak pidana, berkaitan dengan masalah subjek tindak pidana yang umumnya sudah dirumuskan oleh pembuat undang-undang untuk tindak pidana yang bersangkutan. ${ }^{12}$

Pelaku tindak pidana dapat disebut sebagai subjek hukum, dapat di klasifikan menjadi 2 (dua) yaitu pelaku dalam artian manusia sebagai subjek hukum pendukung hak dan kewajiban dan pelaku korporasi. ${ }^{13}$ Pelaku perorangan, dibagi menjadi dua kategori yang didasarkan atas perannya dalam suatu perbuatan pidana yang terdiri dari orang yang melakukan suatu daad itu disebut sebagai seorang dader, dan orang yang turut melakukan perbuatan pidana sebagai pleger. Dalam ilmu pidana, tidak lazim orang mengatakan, bahwa pelaku itu telah membuat suatu tindak pidana, akan tetapi lazim dikatakan orang adalah bahwa seorang pelaku itu telah melakukan suatu tindak pidana. ${ }^{14}$

Peranan dari pelaku bisa berbentuk penyertaan yang telah dirumuskan dalam Pasal 55 KUHP dan Pasal 56 KUHP, yaitu:

Pasal 55 ayat (1) dipidana sebagai pembuat (dader) sesuatu perbuatan pidana:

Ke-1 mereka yang melakukan, yang menyuruh lakukan dan yang turut serta melakukan perbuatan;

Ke-2 mereka yang dengan memberi atau menjanjikan sesuatu, dengan menyalahgunakan kekuasaan atau martabat, dengan kekerasan, ancaman atau penyesatan, atau dengan memberi kesempatan, sarana atau keterangan, sengaja menganjurkan orang lain supaya melakukan perbuatan.

\footnotetext{
${ }^{11}$ Soeharti RM, Hukum Pidana Materiil (Sinar Grafika).[5].

12 Sudarto, Hukum dan Perkembangan Masyarakat (Sinar Baru).[89].

${ }^{13}$ Chairul Huda, Dari Tiada Pidana Tanpa Kesalahan Menuju Kepada Tiada Pertanggungjawaban Pidana Tanpa Kesalahan (Prenada Media 2006).[2].

14 ibid.
} 
Menurut Pasal 55 ayat (1) KUHP, yang dimaksud dengan pelaku tindak pidana ada 4 (empat), yaitu :

1. Mereka yang melakukan yaitu orang yang disebut sebagai pembuat pelaksana;

2. Yang menyuruh lakukan yaitu orang yang disebut sebagai pembuat penyuruh;

3. Yang turut serta melakukan yaitu orang yang disebut sebagai pembuat peserta;

4. Orang yang menganjurkan yaitu orang yang disebut sebagai pembuat penganjur.

Dalam hal ini, pelaku harus terdiri sedikitnya dua orang yaitu orang yang melakukan (pleger) dan juga orang yang turut melakukan (medepleger) yang samasama melakukan perbuatan maka harus ada kerja sama yang didasari antara para pelaku yang memiliki niat dan tujuan yang sama untuk melakukan suatu tindak pidana.

\section{Pasal 56 KUHP}

Dihukum sebagai orang yang membantu melakukan kejahatan:

(1) Barangsiapa dengan sengaja membantu melakukan kejahatan itu;

(2) Barangsiapa dengan sengaja memberikan kesempatan, daya upaya, atau keterangan untuk melakukan kejahatan itu.

Pasal ini menjelaskan bahwa orang yang "membantu melakukan" yaitu dengan sengaja memberikan bantuan pada waktu atau sebelum dilaksanakannya kejahatan tersebut maka kehendak dari orang yang membantu melakukan hanyalah untuk membantu pelaku utama mencapai tujuannya tanpa memiliki tujuan sendiri.

Masalah pertanggungjawaban pidana berkaitan erat dengan unsur kesalahan, ada 3 (tiga) pengertian dasar dalam hukum pidana, yaitu: ${ }^{15}$ a. sifat melawan hukum (unrecht); b. kesalahan (schuld); dan c. pidana (strafe).

Unsur kesalahan ialah unsur yang penting untuk memutuskan akibat dari suatu perbuatan seseorang yang berupa penjatuhan pidana. Asas tiada pidana tanpa kesalahan dalam ilmu hukum pidana dapat dilihat dari hukum pidana yang menitikberatkan kepada perbuatan orang beserta akibatnya (tatstrafrecht atau erfolgstrafrecht) kearah hukum pidana pada orang yang melakukan tindak pidana (taterstrafrecht), tanpa meninggalkan sifat dari tatstrafrecht. Kesalahan itu mengandung unsur pencelaan terhadap seseorang yang telah melakukan tindak pidana. ${ }^{16}$

\footnotetext{
15 ibid.[68].

16 ibid.
} 
Berdasarkan uraian mengenai pengertian kesalahan, maka kesalahan adalah dasar untuk mempertanggungjawabkan pidana. Kesalahan merupakan keadaan jiwa dari si pembuat dan hubungan batin antara si pembuat dengan perbuatannya. Mengenai keadaan jiwa dari seseorang yang melakukan perbuatan disebut sebagai kemampuan bertanggungjawab, sedangkan hubungan batin antara si pembuat dengan perbuatannya itu merupakan kesengajaan, kealpaan, serta alasan pemaaf. Dengan demikian, untuk menentukan adanya kesalahan seseorang harus memenuhi beberapa unsur, antara lain: a. adanya kemampuan bertanggungjawab pada si pembuat; b. hubungan batin antara si pembuat dengan perbuatannya yang berupa kesengajaan (dolus) atau kealpaan (culpa) ini disebut bentuk kesalahan; dan c. tidak adanya alasan penghapusan kesalahan atau tidak ada alasan pemaaf. ${ }^{17}$

Pertanggungjawaban pidana dalam hukum pidana dikenal dengan adanya tiga unsur pokok, yaitu: ${ }^{18}$

1. Unsur perbuatan

Perbuatan atau tindakan seseorang yang dimana perbuatan orang ini adalah titik penghubung dan dasar untuk pemberian pidana

2. Unsur orang atau pelaku

Orang atau pelaku adalah subjek tindak pidana. Hubungan tersebut berkaitan dengan batinyang dimana perbuatanyang dilarang dapat dipertanggungjawabkan pada si pelaku dan baru akan tercapai apabila suatu tindak pidana yang pelakunya dapat dikenakan sanksi pidana.

3. Unsur pidana

Pidana adalah penderitaan yang sengaja dibebankan kepada orang yang melakukan perbuatan yang memenuhi syarat tertentu

Dengan demikian, berdasarkan unsur yang sudah disebutkan di atas yaitu ketiga unsur dalam kesalahan merupakan kesatuan yang tidak bisa dipisahkan. Saling bergantung pada yang lain, dengan demikian urutannya dan yang disebut kemudian bergantung kepada yang disebut terlebih dahulu.Orang tua yang sengaja

\footnotetext{
17 ibid. [73].

18 Sudarto, Hukum Pidana, (Fakultas Hukum UNDIP 1997).[64].
} 
membiarkan ataupun sengaja menjadikan anak kandung mereka menjadi pengemis dan pengamen termasuk dalam suatu tindak pidana yang dimana orang tua dari anak tersebut harus bertanggung jawab karena telah melakukan penelantaran anak dengan cara tidak memenuhi kehutuhan pokok anak tersebut yang mengakibatkan anak tersebut dengan terpaksa turut bekerja demi memenuhi kebutuhan hidupnya. Dalam hal ini, maka orang tersebut telah melakukan eksploitasi secara ekonomi dan eksploitasi secara sosial yang dengan sengaja menelantarkan anak sehingga membiarkan anak mereka bekerja demi memenuhi kebutuhan pokok keluarga yang seharusnya menjadi tanggung jawab orang tua.

Undang-Undang Nomor 23 Tahun 2004 Tentang Penghapusan Kekerasan Dalam Rumah Tangga (UU PKDRT), tidak secara eksplisit mengatur larangan terhadap orang tua dalam menjadikan anaknya sebagai pengemis dan pengamen. Namun secara implisit termasuk dalam tindak pidana penelantaran anak yang dimana kebutuhan pokok maupun hak anak tidak dipenuhi oleh orang tua. Larangan tersebut diatur dalam ketentuan Pasal 9 jo. Pasal 49 UU PKDRT.

Pasal 9

(1) Setiap orang dilarang menelantarkan orang dalam lingkup rumah tangganya, padahal menurut hukum yang berlaku bagianya atau karena persetujuan atau perjanjian ia wajib memberikan kehidupan, perawatan, atau pemeliharaan kepada orang tersebut

(2) Penelantaran sebagaimana dimaksud pada ayat (1) juga berlaku bagi setiap orang yang mengakibatkan ketergantungan ekonomi dengan cara membatasi dan/atau melarang untuk bekerja yang layak di dalam atau di luar rumah sehingga korban berada di bawah kendali orang tersebut.

Dalam pasal ini menurut saya, bisa menjadi awal mula terjadinya eksploitasi ekonomi yang dengan sengaja mengabaikan atau menelantarkan kebutuhan dari orang yang masih membutuhkan perawatan ataupun pemeliharaan orang tersebut. pada saat orang yang ditelantarkan dalam keadaan tidak berdaya maka dengan terpaksa orang tersebut turut bekerja untuk memenuhi kebutuhan diri sendiri maupun bersama dengan berbagai macam modus operandi termasuk menjadikan orang tersebut sebagai pengemis dan pengamen. 
Pasal 49

Dipidana dengan pidana penjara paling lama 3 (tiga) tahun atau denda paling banyak Rp 15.000.000,00 (lima belas juta rupiah), setiap orang yang:

a. Menelantarkan orang lain dalam lingkup rumah tangganya sebagaimana dimaksud dalam Pasal 9 ayat (1);

b. Menelantarkan orang lain sebagaimana dimaksud dalam Pasal 9 ayat (2).

Dalam pasal tersebut memberikan sanksi pidana yang diberikan kepada orang tua maupun keluarga yang dengan sengaja menelantarkan orang lain yang juga bisa diartikan sebagai anak yang dimana butuh untuk dilindungi dan dipelihara oleh orang tua maupun keluarga.

Ketentuan yang terkait dengan seseorang yang bisa diartikan orang tua juga diatur dalam Undang-Undang Nomor 13 Tahun 2003 tentang Ketenagakerjaan, yakni:

Pasal 184

(1) Barang siapa melanggar ketentuan sebagaimana dimaksud dalam Pasal 74, dikenakan sanksi pidana penjara paling singkat 2 (dua) tahun dan paling lama 5 (lima) tahun dan/atau denda paling sedikit Rp 200.000.000,- (dua ratus juta rupiah) dan paling banyak Rp 500.000.000,- (lima ratus juta rupiah)

(2) Tindak pidana sebagaimana dimaksud dalam ayat (1) merupakan tindak pidana kejahatan

Pasal ini menjelaskan bahwa tindak kejahatan yang dengan sengaja menempatkan anak dalam kondisi terburuk dapat dikenakan sanksi pidana karena telah melanggar hak anak untuk hidup dengan layak. Tindak kejahatan tersebut juga dapat dilakukan oleh orang tua.

Beberapa ketentuan yang terkait dengan kewajiban untuk memberikan perlindungan khusus terhadap anak diatur dalam beberapa ketentuan pasal dalam Undang-Undang Nomor 35 Tahun jo.Undang-Undang Nomor 23 Tahun 2002 Tentang Perlindungan Anak, yakni:

Pasal 66

Perlindungan Khusus bagi Anak yang dieksploitasi secara ekonomi dan/ atau seksual sebagaimana Pasal 59 ayat (2) huruf d dilakukan melalui:

a. Penyebarluasan dan/atau sosialisasi ketentuan peraturan perundang-undangan yang berkaitan dengan Perlindungan Anak yang dieksploitasi secara ekonomi dan/atau seksual;

b. Pemantauan, pelaporan, dan pemberian sanksi; dan 
c. Pelibatan berbagai perusahaan, serikat pekerja, lembaga swadaya masyarakat, dan masyarakat dalam penghapusan eksploitasi terhadap Anak secara ekonomi dan/atau seksual.

Eksploitasi secara ekonomi yang dilakukan tanpa persetujuan anak sehingga anak tersebut menjadi korban tetapi eksploitasi ini tidak hanya terbatas pada pelacuran, kerja atau pelayanan paksa, perbudakan atau praktik serupa perbudakan, penindasan, pemerasan, pemanfaatan fisik, seksual, organ reproduksi, atau secara melawan hukum memindahkan atau mentransplantasi organ dan/atau jaringan tubuh atau memanfaatkan tenaga atau kemampuan anak oleh pihak lain untuk mendapatkan keuntungan materiil.

\section{Pasal 77B}

Setiap orang yang melanggar ketentuan sebagaimana dimaksud dalam Pasal 76B, dipidana dengan pidana penjara paling lama 5 (lima) tahun dan/aatu denda paling banyak Rp. 100.000.000,- (seratus juta rupiah)

Pasal 76 I

Setiap orang dilarang menempatkan, membiarkan, melakukan, menyuruh melakukan, atau turut serta melakukan eksploitasi secara ekonomi dan/atau seksual terhadap anak.

Pasal 88

Setiap orang yang melanggar ketentuan sebagaimana dimaksud dalam Pasal 76I, dipidana dengan penjara paling lama 10 (sepuluh) tahun dan/atau denda paling banyak Rp. 200.000.000,00 (dua ratus juta rupiah)

Undang-Undang Perlindungan anak mengatur tentang larangan mengeksploitasi anak secara ekonomi dan/atau seksual. Seorang anak yang menjadi korban eksploitasi secara ekonomi dan/atau seksual mendapatkan perlindungan khusus dari Negara sedangkan bagi pelaku eksploitasi anak sebagaimana diatur dalam Pasal 88 nya yang menyebutkan "Setiap orang yang melanggar ketentuan sebagaimana dimaksud dalam Pasal 76 I, dipidana dengan penjara paling lama 10 (sepuluh) tahun dan/atau denda paling banyak Rp. 200.000.000,00 (dua ratus juta rupiah)”.

Pada Putusan Pengadilan Negeri Malang dengan Nomor: 624/PID.B/2016/ PN.MLG menjatuhkan putusan terhadap Orang Tua yang dengan sengaja menjadikan anak sebagai pengamen dan pengemis merupakan suatu tindak kejahatan dan masyarakat masih belum banyak mengerti dan menyadari jika tindak pidana tersebut sering terjadi di sekitar mereka. Larangan eksploitasi ekonomi terhadap anak diatur 
di dalam Pasal 76I Undang-Undang Perlindungan Anak yang menyatakan "setiap orang dilarang menempatkan, membiarkan, melakukan, menyuruh melakukan, atau turut serta melakukan eksploitasi secara ekonomi dan/atau seksual terhadap anak".

Analisis kasus di dalam putusan tersebut telah terjadi perbuatan eksploitasi ekonomi terhadap anak yang dilakukan oleh terdakwa dengan menyuruh anak kandungnya yang masih dibawah umur untuk mengamen di perempatan jalan kaliurang Malang Kota, setelah selesai mengamen keuntungan yang didapat diserahkan kepada Terdakwa yang dipergunakan untuk memenuhi kebutuhan hidup keluarga. Dalam kasus tersebut telah memenuhi unsur-unsur yang sekaligus dijadikan pertimbangan oleh hakim yaitu: 1. Setiap Orang yakni terdakwa. 2. Melakukan (menyuruh melakukan) yakni telah menyuruh anak kandungnya untuk mengamen mengingat usia anak tersebut masih dibawah umur. Dimana unsurunsur tersebut telah diperkuat oleh alat bukti yang disebutkan maka terdakwa telah terbukti secara sah bersalah dan melanggar ketentuan Pasal 76I Undang-Undang Perlindungan Anak dan Hakim Pengadilan Negeri Malang telah tepat dalam menimbang dan memutus perkara kasus ini karena unsur-unsur dan alat bukti telah sesuai dengan pasal yang di dakwakan terhadap terdakwa.

\section{Kesimpulan}

Orang tua yang sengaja menjadikan anak sebagai pengemis maupun pengamen termasuk dalam tindak pidana masuk kategori melakukan eksploitasi terhadap anak secara ekonomi. Pada dasarnya eksploitasi ekonomi dapat terjadi melalui penelantaran anak dengan tidak memenuhi kebutuhan anak sehingga memaksa anak untuk turut membantu mencari uang demi memenuhi kebutuhan pokok keluarga. yang diatur di Pasal 297, 301, 304, 328, 333 ayat (1) dan 334 ayat (1) KUHP. Pasal 74 UU Ketenagakerjaan. Pasal 5 dan Pasal 9 ayat (1) UU Penghapusan KDRT. Pasal 1 angka 7 dan angka 11 UU TPPO. Pasal 1 angka 4, Pasal 89, Pasal 90 ayat (1), Pasal 91 UU SPPA. Pasal 1 angka 12, Pasal 20, Pasal 26 ayat (1), Pasal 33 ayat (1), Pasal 45, Pasal 59, Pasal 60, Pasal 76B, Pasal 76I UU Perlindungan Anak. Pertanggungjawaban orang tua sebagai pelaku yang menjadikan anak kandung 
sebagai pengemis dan pengamen diatur dalam UU Penghapusan Kekerasan Dalam Rumah Tangga pada Pasal 9 dan Pasal 49 dengan melakukan penelantaran terhadap anak sebagai awalan dalam melakukan eksploitasi ekonomi dengan modus operandi menjadikan anak sebagai pengemis dan pengamen. Dalam UU Perlindungan Anak Pasal 76I dan juga Pasal 88 dengan hukuman penjara paling lama 10 (sepuluh) tahun dan/atau denda paling banyak Rp. 200.000.000,00 (dua ratus juta rupiah).

\section{Daftar Bacaan}

\section{Buku}

Abu Huraerah, Kekerasan Terhadap Anak (Penerbit Nuansa 2006).

B. Bosu, Sendi-Sendi Kriminologi (Usaha Nasional 1982).

Bagong Suyanto, Analisis Situasi Pekerja Anak dan Permasalahan PendidikanDasar di Jawa Timur (Universitas Airlangga Press 1999).

Chairul Huda, Dari Tiada Pidana Tanpa Kesalahan Menuju Kepada Tiada Pertanggungjawaban Pidana Tanpa Kesalahan (Prenada Media 2006).

Didik Endro P, Hukum Pidana (Khusus Untuk Mahasiswa Fakultas Hukum Universitas Airlangga 2010).

Kartini Kartono, Patologi Sosial (Raja Grafindo Persada 2005).

Maidin Gultom, Perlindungan Hukum Terhadap Anak dalam Sistem Peradilan Pidana Anak di Indonesia (PT. Refika Aditama 2008).

Peter Mahmud Marzuki, Penelitian Hukum (Prenamedia Group 2011).

Romli Atmasita, Pengantar Hukum Pidana Internasional; (Rafika Aditama, 2000).

Sholeh Soeaidy, dan Zulkhair, Dasar Hukum Perlindungan Anak (Novindo Pustaka Mandiri 2001).

Soeharti RM, Hukum Pidana Materiil (Sinar Grafika).

Sudarto, Hukum dan Perkembangan Masyarakat (Sinar Baru 1983).

Sudarto, Hukum Pidana (Fakultas Hukum UNDIP 1997). 
Waluyudi, Hukum Perlindungan Anak (Mandar Maju 2009).

Wirjono Prodjodikoro, Asas-Asas Hukum Pidana di Indonesia (PT. Refika Aditama 2008).

\section{Laman}

https://news.detik.com/berita/d-3868986/kpai-dalami-kasus-bocah-lemas-diminimarket-yang-dimanfaatkan-ngamen diakses pada Tanggal 10 Mei 2019

\section{Perundang-undangan}

Undang Undang Dasar Negara Republik Indonesia Tahun 1945.

Undang-Undang Nomor 1 Tahun 1946 tentang Peraturan Hukum Pidana.

Undang-Undang Nomor 4 Tahun 1979 tentang Kesejahteraan Anak, Lembaran Negara Tahun 1979, Nomor 33, (Tambahan Lembaran Negara Nomor 3142).

Undang-Undang Nomor 13 Tahun 2003 tentang Ketenagakerjaan, (Tambahan Lembaran Negara Republik Indonesia Nomor 4279).

Undang-Undang Nomor 23 Tahun 2004 tentang Penghapusan Kekerasan Dalam Rumah Tangga, Lembaran Negara Tahun 2004, Nomor 95, (Tambahan Lembaran Negara Nomor 4419 Tahun 2004).

Undang-Undang Nomor 21 Tahun 2007 tentang Tindak Pidana Perdagangan Orang, (Lembaran Negara Tahun 2007, Nomor 58, Tambahan Lembaran Negara Nomor 4720).

Undang-Undang Nomor 11 Tahun 2012 tentang Sistem Peradilan Pidana Anak, (Lembaran Negara Tahun 2012, Nomor 153, Tambahan Lembaran Negara Nomor 5332).

Undang-Undang Nomor 35 Tahun 2014 tentang Perubahan Atas Undang-Undang Nomor 23 Tahun 2002 tentang Perlindungan Anak, (Lembaran Negara Tahun 2014, Nomor 297, Tambahan Lembaran Negara Nomor 5606). 